\title{
MENINGKATKAN KOMPETENSI PROFESIONAL KONSELOR DALAM PEMBENTUKAN KARAKTER CERDAS SISWA MIN SUNGAI TARAB (SEBUAH PILOTING PROJECT DI MIN SUNGAI TARAB)
}

\author{
Hadiarni \\ Program Studi Bimbingan Konseling, Jurusan Tarbiyah, STAIN Batusangkar \\ Korespondensi: Jl. SimpangArai Pinang I Kuburajo, Limakaum, Batusangkar, Sumatera Barat \\ e-mail: hadiarni_rais@yahoo.co.id
}

\begin{abstract}
This research was aimed at conducting a piloting project on improving professional competency of guidance teacher in promoting smart character of Islamic Elementary School (MIN) Sungai Tarab). To achieve the goal, qualitative approach and collaborative action research were employed. The subjects of the research were a guidance teacher and other school personnels. The subjects were chosen by means of purposive sampling technique since they were chosen in line with the purpose of the research. Data were collected by following the principles qualitative paradigm where the researcher was the key instrument, and observation, interview and documentary study were used. The research steps basically followed those of action research. Those steps were: 1) Intial reflction, 2) Planning, 3) action and observation, dan 4) reflection. Data analysis was carried out during data collection by referring to Miles dan Huberman's which consisted of three main steps: 1) data reduction, 2) data display, and 3) conclusion/verification. The finding of this research show that the delopment took place for several indicators of professional competency of the guidance teacher in terms of improving her horizon and knowledge and skill in administering and following up inventory (AUM) while other indicators cannot be improve due to time constrains from the subject of the research.
\end{abstract}

Kata kunci: kompetensi profesional, konselor, karakter cerdas, MIN Sungai Tarab

\section{PENDAHULUAN}

U U Sisdiknas No 20 tahun 2003 pasal 3 menegaskan bahwa pendidikan nasional berfungsi mengembangkan kemampuan dan membentuk watak serta peradaban bangsa yang bermartabat dalam rangka mencerdaskan kehidupan bangsa, bertujuan untuk berkembangnya potensi peserta didik agar menjadi manusia yang beriman dan bertakwa kepada Tuhan Yang Maha Esa, berakhlak mulia, sehat, cakap, kreatif, mandiri dan menjadi warga Negara yang demokratis serta bertanggungjawab". Fungsi dan tujuan pendidikan nasional di atas menegaskan bahwa pendidikan, pada jenjang apapun, termasuk di Sekolah Dasar (SD), Madrasah Ibtidaiyah (MI) dan sederajat, harus dilaksanakan secara sistematis mengingat SD dan MI merupakan lembaga pendidikan formal pertama yang memberikan anak keterampilan-keterampilan dasar, seperti membaca, menulis dan berhitung. Di samping itu, 
anak akan mempelajari pengetahuan umum serta perkembangan kepribadian seperti sikap terbuka terhadap orang lain, penuh inisiatif, kreativitas dan kepemimpinan.

Selanjutnya, berkaitan dengan perkembangan kepribadian bagi siswa SD adalah penemuan diri sendiri. Menurut Yusuf Gunawan (1992: 178) penemuan dan pemahaman diri sendiri harus sudah diproses sejak awal di sekolah dasar, karena hal tersebut akan membantu anak melakukan penyesuaian-penyesuaian terhadap situasi baru, mengembangkan kemampuan mereka untuk memahami diri sendiri dan menerapkannya dalam situasi mendatang. Dengan demikian, pendidikan pada tingkatan SD merupakan landasan bagi perkembangan kecerdasan serta pembentukan watak dan karakter seorang individu. Usia sekolah dasar diyakini sebagai periode yang sangat potensial dalam pembentukan karakter. Semakin dini dilakukan usahausaha pembentukan karakter terhadap anak, semakin besar peluang untuk melahirkan generasi yang memiliki karakter yang pada gilirannya akan memberikan kontribusi kepada masyarakat dan bangsa yang berkarakter.

Lebih lanjut, perkembangan kecerdasan serta pembentukan watak dan karakter individu tidak dapat diperoleh hanya melalui pengajaran semata, karena itulah dibutuhkan pelayanan bimbingan dan konseling. Pelayanan konseling dibutuhkan pada setiap jenjang pendidikan, tidak terkecuali di sekolah dasar. Menurut Sunaryo Kartadinata, dkk (1998: 11-12) pendidikan di sekolah dasar (SD) tidak hanya mengantarkan siswanya untuk tamat belajar, melainkan harus membantu siswa mengembangkan kesiapan baik dari segi akademik, sosial, maupun pribadi untuk memasuki proses pendidikan di SLTP. Kebutuhan akan layanan bimbingan dan konseling di SD bertolak dari kebutuhan dan masalah perkembangan siswa, serta rentang keragaman individual siswa yang amat lebar. Untuk itu, yang menjadi target populasi layanan bimbingan di SD adalah; (1) siswa dengan kecerdasan dan kemampuan tinggi; (2) siswa yang mengalami kesulitan belajar; dan (3) siswa dengan perilaku bermasalah. Selanjutnya, Juntika Nurihsan (2003:70) menyatakan bahwa: pelayanan bimbingan dan konseling perlu diselenggarakan di sekolah dasar agar pribadi dan segenap potensi yang dimiliki siswa dapat berkembang secara optimal. Pelayanan bimbingan dan konseling di SD perlu disesuaikan dengan berbagai kekhususan pendidikan di SD, terutama yang menyangkut karakteristik peserta didik, tujuan pendidikannya dan para pelaksananya yaitu guru kelas.

Berkaitan dengan pelaksana bimbingan dan konseling di SD, dalam Peraturan Menteri Negara Pendayagunaan Aparatur Negara dan Reformasi Birokrasi Nomor 16 Tahun 2009 tentang Jabatan Fungsional Guru dan Angka Kreditnya Pasal 13 menegaskan bahwa guru kelas memiliki tugas, antara lain sebagai berikut: a) menyusun kurikulum pembelajaran pada satuan pendidikan; b) menyusun silabus pembelajaran; c) menyusun rencana pelaksanaan pembelajaran; d) melaksanakan kegiatan pembelajaran; e) menyusun alat ukur/soal sesuai mata pelajaran; f) menilai dan mengevaluasi proses dan hasil belajar pada mata pelajaran di kelasnya; g) menganalisis hasil penilaian pembelajaran; h) melaksanakan pembeljaran/perbaikan dan pengayaan dengan memanfaatkan hasil penilaian dan evaluasi; i) melaksanakan bimbingan dan konseling di kelas yang menjadi tanggung jawabnya.

Lain halnya dengan Madrasah Ibtidaiyah (MI) yang merupakan pen- 
didikan setingkat SD, dalam buku petunjuk pelaksanaan Administrasi Pendidikan di Madrasah Ibtidaiyah (1995: 4) pada Bab II tentang Struktur organisasi dinyatakan bahwa Konselor merupakan salah satu komponen yang ada di samping Wali Kelas, Guru Mata Pelajaran, Guru Kelas dan Tenaga Kependidikan lainnya. Kutipan ini menjelaskan bahwa di MI konselor merupakan tenaga khusus yang disediakan untuk melaksanakan bimbingan dan konseling. Lebih lanjut, dalam tugas dan fungsinya, dalam membantu Mekanisme Kerja Pengelolaan Madrasah, Konselor melaksanakan kegiatan: 1) konseling, 2) pembentukan pribadi siswa, 3) membantu siswa memecahkan masalah, dan 4) administrasi bimbingan dan konseling.

Menyadari akan peranan strategis yang diberikan kepada konselor di MI, Madrasah Ibtidaiyah Negeri (MIN) Sungai Tarab telah memiliki seorang konselor khusus yang telah memiliki SK definitif dari pemerintah. Konselor ini merupakan satu-satunya konselor yang ada di tingkat SD/MI sederajat di Kabupaten Tanah Datar. Idealnya, dengan sudah tersedianya konselor khusus ini diharapkan pelaksanaan bimbingan dan konseling di sekolah lebih terarah karena ditangani oleh tenaga khusus yang profesional. Konselor khusus ini diharapkan dapat menunjukkan kompetensi profesionalnya, sehingga MIN Sungai Tarab bisa menjadi piloting project pelaksanaan bimbingan dan konseling pada tingkat SD, MI dan sederajat, khususnya di kabupaten Tanah Datar. Namun kenyataannya, berdasarkan hasil wawancara penulis dengan konselor di MI ini terungkap bahwa beliau kesulitan dalam merancang program pelayanan konseling mengingat yang bersangkutan tidak memiliki latar belakang bimbingan dan konseling. Sebagai alumni Fakultas Dakwah dari Jurusan Bimbingan dan
Penyuluhan Islam dan dibekali dengan Akta mengajar, yang bersangkutan merasa belum disiapkan untuk terjun ke dalam bidang bimbingan dan konseling. Selanjutnya, dalam melaksanakan kegiatan layanan bimbingan dan konseling beberapa kendala yang ditemui karena tidak adanya jam khusus untuk masuk kelas, tidak adanya Kelompok Kerja Madrasah (KKM) yang membahas tentang bimbingan dan konseling karena tidak adanya sejawat yang memiliki latar belakang konselor di sekolah dasar. Beberapa kondisi di atas membuat yang bersangkutan belum dapat melaksanakan tugas pokoknya sebagai konselor.

Mengacu kepada urgensi pembentukan karakter pada siswa SD/MI melalui layanan bimbingan dan konseling, serta fenomena yang terjadi pada konselor di MIN Sungai Tarab, peneliti tertarik untuk melakukan sebuah penelitian tindakan kemitraan (Collaborative Action Research) pada MIN Sungai Tarab sehingga kegiatan pelayanan konseling dapat berjalan sebagaimana yang diharapkan.

Berdasarkan latar belakang masalah di atas, masalah penelitian ini dirumuskan sebagai berikut: "Bagaimanakah meningkatkan kompetensi profesional konselor dalam pembentukan karakter cerdas siswa MIN Sungai Tarab?". Secara lebih rinci batasan masalah dijabarkan sebagai berikut: 1) Bagaimanakah meningkatkan kompetensi profesional konselor dalam pembentukan karakter cerdas siswa dalam hal wawasan, pengetahuan, nilai dan sikap profesional bimbingan dan konseling di MIN Sungai Tarab?, 2) Bagaimanakah meningkatkan kompetensi profesional konselor dalam pembentukan karakter cerdas siswa dalam hal perancangan program bimbingan dan konseling di MIN Sungai Tarab?, 3) Bagaimanakah meningkatkan kompe- 
tensi profesional konselor dalam pembentukan karakter cerdas siswa dalam hal pelaksanaan program bimbingan dan konseling di MIN Sungai Tarab?

Sasaran penelitian ini adalah konselor di MIN Sungai Tarab demi terwujudnya konselor professional di MIN Sungai Tarab sehingga diharapkan dapat menjadi piloting project bagi pelaksanaan bimbingan dan konseling di SD, MI dan sederajat. Selanjutnya Kepala Madrasah sebagai penanggung jawab seluruh kegiatan dan sebagai pengambil kebijakan, sehingga diharapkan dapat mendukung pelaksanaan bimbingan dan konseling. Guru kelas sebagai mitra konselor dalam pelaksanaan bimbingan dan konseling di Madrasah diharapkan dapat bekerjasama dalam pelaksanaan kegiatan bimbingan dan konseling.

Selanjutnya penelitian ini bertujuan untuk meningkatkan kompetensi profesional konselor dalam pembentukan karakter cerdas siswa MIN Sungai Tarab?". Secara lebih penelitian ini bertujuan untuk: 1) meningkatkan kompetensi profesional konselor dalam pembentukan karakter cerdas siswa dalam hal wawasan, pengetahuan, nilai dan sikap profesional bimbingan dan konseling di MIN Sungai Tarab. 2) meningkatkan kompetensi profesional konselor dalam pembentukan karakter cerdas siswa dalam hal perancangan program bimbingan dan konseling di MIN Sungai Tarab dan 3) meningkatkan kompetensi profesional konselor dalam pembentukan karakter cerdas siswa dalam hal pelaksanaan program bimbingan dan konseling di MIN Sungai Tarab.

\section{METODE}

Penelitian ini menggunakan pendekatan deskriptif kualitatif sedangkan jenis penelitiannya adalah penelitian tindakan kemitraan (collaborative action research). Penelitian tindakan kemitraan ini dilaksanakan untuk membantu konselor dalam meningkatkan kompetensi profesionalnya dalam hal meningkatkan wawasan, pengetahuan, nilai dan sikap profesional bimbingan dan konseling serta perancangan pelaksanaan dan evaluasi program bimbingan dan konseling di sekolah dasar, sehingga layanan yang diberikan sesuai dengan kebutuhan siswa yang pada akhirnya bermuara pada peningkatan karakter cerdas siswa.

Penelitian tindakan kemitraan ini pada dasarnya mengadopsi pola dan tahapan penelitian tindakan (action research) pada umumnya. Secara sederhana, rencana tindakan mengacu kepada model Spiral Kemmis dan Taggart dengan melalui beberapa siklus tindakan. Dalam setiap siklusnya memiliki 4 komponen, meliputi: Perencanaan, aksi/tindakan, observasi, refleksi. Sementara itu fokus penelitian dalam setiap siklus adalah meningkatkan kompetensi profesional konselor dalam meningkatkan karakter cerdas siswa MIN Sungai Tarab melalui pemberian wawasan dan keterampilan dalam melaksanakan konseling mulai dari persiapan sampai evaluasi.

Mengacu kepada hakikat penelitian kualitatif, dalam penelitian ini peneliti merupakan instrument kunci. Sebagai human instrument, peneliti memiliki fungsi dalam menetapkan fokus penelitian, memilih informan sebagai sumberdata, melakukan pengumpulan data, analisis data dan membuat kesimpulan atas temuannya (Sugiyono, 2009: 222).

Teknik pengumpulan data yang akan digunakan adalah pengamatan (observasi), wawancara dan analisis dokumen. Sedangkan alat pengumpul data yang digunakan adalahah pedoman wawancara dan lembaran observasi. 


\section{PEMBAHASAN}

\section{Tinjauan Pustaka}

\section{Kompetensi Profesional Konselor}

Salinan Lampiran Peraturan Menteri Pendidikan Nasional Nomor 27 Tahun 2008 Tanggal 11 Juni 2008 tentang Standar Kualifikasi Akademik Dan Kompetensi Konselor menegaskan bahawa keberadaan konselor dalam sistem pendidikan nasional dinyatakan sebagai salah satu kualifikasi pendidik, sejajar dengan kualifikasi guru, dosen, pamong belajar, tutor, widyaiswara, fasilitator, dan instruktur (UU No. 20 Tahun 2003 Pasal 1 Ayat 6). Masingmasing kualifikasi pendidik, termasuk konselor, memiliki keunikan konteks tugas dan ekspektasi kinerja. Standar kualifikasi akademik dan kompetensi konselor dikembangkan dan dirumuskan atas dasar kerangka pikir yang menegaskan konteks tugas dan ekspektasi kinerja konselor.

Sosok utuh kompetensi konselor mencakup kompetensi akademik dan profesional sebagai satu keutuhan. Kompetensi akademik merupakan landasan ilmiah dari kiat pelaksanaan pelayanan profesional bimbingan dan konseling. Kompetensi akademik merupakan landasan bagi pengembangan kompetensi profesional, yang meliputi: (1) memahami secara mendalam konseli yang dilayani, (2) menguasai landasan dan kerangka teoretik bimbingan dan konseling, (3) menyelenggarakan pelayanan bimbingan dan konseling yang memandirikan, dan (4) mengembangkan pribadi dan profesionalitas konselor secara berkelanjutan. Unjuk kerja konselor sangat dipengaruhi oleh kualitas penguasaan ke empat kompetensi tersebut yang dilandasi oleh sikap, nilai, dan kecenderungan pribadi yang mendukung.

Pembentukan kompetensi akademik konselor ini merupakan proses pendidikan formal jenjang strata satu (S1) bidang Bimbingan dan Konseling. Selanjutnya kompetensi profesional merupakan penguasaan kiat penyelenggaraan bimbingan dan konseling yang memandirikan, yang ditumbuhkan serta diasah melalui latihan menerapkan kompetensi akademik yang telah diperoleh dalam konteks otentik Pendidikan Profesi Konselor yang berorientasi pada pengalaman dan kemampuan praktik lapangan, dan tamatannya memperoleh sertifikat profesi bimbingan dan konseling dengan gelar profesi Konselor, disingkat Kons.

Secara lebih khusus, Salinan Lampiran Peraturan Menteri Pendidikan Nasional Nomor 27 Tahun 2008 Tanggal 11 Juni 2008 tentang Standar Kualifikasi Akademik Dan Kompetensi Konselor menjabarkan kompetensi professional seorang konselor sebagai berikut: 1) Menguasai konsep dan praksis asesmen untuk memahami kondisi, kebutuhan, dan masalah konseli, 2) Menguasai kerangka teoretik dan praksis bimbingan dan konseling, 3) Merancang program Bimbingan dan Konseling, 4) Mengimplementasikan program Bimbingan dan Konseling yang komprehensif, 5) Menilai proses dan hasil kegiatan Bimbingan dan Konseling, 6) Memiliki kesadaran dan komitmen terhadap etika professional, 7) Menguasai konsep dan praksis penelitian dalam bimbingan dan konseling

\section{Karakteristik Siswa Sekolah Dasar}

Siswa Sekolah Dasar (SD) adalah mereka yang berusia 6-13 tahun yang sedang menjalani tahap perkembangan masa anak-anak dan memasuki masa remaja awal. Yusuf Gunawan (1992: 180-181) membagi siswa sekolah dasar tersebut kepada dua periode yaitu umur 6-10 tahun dan umur 10-13 tahun. Dalam periode umur 6-10 tahun seluruh bagian tubuh anak berkembang, per- 
tumbuhan dan koordinasi otot masih belum merata, tetapi perkembangan koordinasi mata dan tangan telah cukup sehingga dapat dipakainya untuk menulis, menggambar, menjahit dan memainkan alat music. Selanjutnya periode usia 10-13 tahun, anak kelihatan aktif dan selalu ingin bergerak.

Perkembangan periodesasi di atas akan sangat terkait dengan tugas perkembangan yang harus dicapai oleh anak usia sekolah dasar. Dalam buku Pelayanan Bimbingan dan Konseling berbasis kompetensi Sekolah Dasar, Madrasah Ibtidaiyah sederajat (2002: 11) diuraikan beberapa tugas perkembangan siswa SD, MI dan sederajat yaitu: 1) menanamkan dan mengembangkan kebiasaan dan sikap dalam beriman dan bertaqwa kepada Tuhan Yang Maha Esa, 2) mengembangkan keterampilan dasar dalam membaca, menulis dan berhitung, 3) mengembangkan konsep-konsep yang diperlukan dalam kehidupan sehari-hari, 4) belajar bergaul dan bekerjasama dengan kelompok teman sebaya, 5) belajar menjadi pribadi yang mandiri, 6) mempelajari keterampilan fisik sederhana yang diperlukan baik untuk permainan maupun kehidupan, 7) mengembangkan kata hati, moral dan nilai-nilai sebagai pedoman perilaku, 8) membina hidup sehat untuk diri sendiri dan lingkungan serta keindahan, 9) belajar memahami diri sendiri dan orang lain sesuai dengan jenis kelaminnya serta menjalankan peran tanpa membedakan jenis kelamin, 10) mengembangkan sikap terhadap kelompok, lembaga sosial serta tanah air, bangsa dan Negara, dan 11) mengembangkan pemahaman dan sikap awal untuk perencanaan masa depan.

Dalam menjalankan tugas perkembangannya tersebut anak sering mengalami hambatan, sehingga anak sering bergantung kepada orang lain. Oleh karena itu, anak usia SD mem- butuhkan perhatian khusus dan bantuan dari para pendidik agar tugas perkembangan dan tujuan pendidikan dapat tercapai dengan baik.

\section{Bimbingan dan Konseling di SD, MI dan Sederajat}

Pelayanan bimbingan dan konseling merupakan bagian integral dari pendidikan dan sangat menentukan bagi pencapaian tujuan tersebut. Untuk itu bimbingan konseling sangat penting diberikan di sekolah mulai dari SD dan seterusnya. Menurut Sunaryo Kartadinata dkk (1998: 1) faktor utama yang melandasi kebutuhan akan layanan bimbingan di sekolah dasar adalah factor karakteristik dan masalah perkembangan siswa. Di samping itu, pada bagian lain Sunaryo Kartadinata dkk (1998: 12) lebih menegaskan bahwa yang menjadi target bimbingan di sekolah dasar adalah a) siswa dengan kecerdasan dan kemampuan tinggi, b) siswa yang mengalami kesulityan belajar dan c) siswa dengan perilaku bermasalah.

Begitu pentingnya keberadaan bimbingan dan konseling di SD dan sederajat, maka dituntut tenaga khusus atau tenaga yang memiliki pemahaman dan kemampuan untuk melaksanakan layanan bimbingan dan konseling. Pada dasarnya BK di SD/MI menjadi tugas dan tanggung jawab guru kelas. Hal ini sebagaimana dinyatakan dalam Peraturan Menteri Negara Pendayagunaan Aparatur Negara dan Reformasi Birokrasi Nomor 16 Tahun 2009 tentang Jabatan Fungsional Guru dan Angka Kreditnya Bab VII Pasal 13 bahwa Rincian kegiatan guru kelas sebagai berikut: a) menyusun kurikulum pembelajaran pada satuan pendidikan, b) menyusun silabus pembelajaran, c) menyusun rencana pelaksanaan pembelajaran, d) melaksanakan kegiatan pembelajaran, e) menyusun alat ukur/soal sesuai mata pelajaran, f) menilai dan mengevaluasi proses dan 
hasil belajar pada mata pelajaran di kelasnya, g) menganalisis hasil penilaian pembelajaran, h) melaksanakan pembelajaran/perbaikan dan pengayaan dengan memanfaatkan hasil penilaian dan evaluasi, i) melaksanakan bimbingan dan konseling pada kelas yang menjadi tanggungjawabnya, dst. Dari kutipan di atas dapat dipahami bahwa di SD/MI guru kelas merupakan penanggung jawab utama pelaksanaan BK di samping tugasnya sebagai pengajar.

Selanjutnya dalam buku pelayanan bimbingan dan konseling berbasis kompetensi Sekolah Dasar, Madrasah Ibtidaiyah sederajat (2002: 21-22) dijelaskan personil pelaksana bimbingan dan konseling di SD/MI sederajat yaitu: 1) Kepala sekolah adalah penanggung jawab pelaksanaan pendidikan dan sekaligus pelayanan bimbingan dan konseling di sekolah, 2) Guru kelas adalah guru yang bertugas melaksanakan dan mengelola pendidikan di kelasnya. Guru kelas ini selain mengajar secara penuh juga melaksanakan pelayanan bimbingan dan konseling terhadap siswa-siswa di kelas yang menjadi tanggung jawabnya, 3) Guru agama/ penjaskes yang secara khusus diberi tugas mengajarkan mata pelajaran tersebut di sekolah yang bersangkutan dan membantu guru kelas dalam pelaksanaan pelayanan bimbingan dan konseling, 4) Konselor: konselor yang berasal dari sekolah lain (misalnya SLTP atau SLTA) dapat membantu penyelenggaraan bimbingan dan konseling di SD/MI sederajat.

Selanjutnya dalam buku Pelayanan Bimbingan dan Konseling berbasis kompetensi Sekolah Dasar, Madrasah Ibtidaiyah sederajat (2002: 15) dijelaskan pola pelayanan bimbingan dan konseling di SD, MI dan sederajat yaitu: a) pola kegiatan kelas sehari-hari, yaitu memasukkan materi bimbingan dan konseling dalam kegiatan kelas sehari-hari, b) pola infuse yaitu memasukkan materi bimbingan dan konseling ke dalam mata pelajaran tertentu, c) pola ekstra-kurikuler, yaitu menyelenggarakan kegiatan bimbingan dan konseling di luar pengajaran dan tanpa melalui jenis layanan/kegiatan pendukung bimbingan dan konseling tertentu melainkan melalui kegiatan lain seperti upacara bendera, d) pola layanan khusus yaitu menyelenggarakan kegiatan bimbingan dan konseling melalui berbagai jenis layanan dan kegiatan pendukung tertentu. Untuk hal ini guru kelas harus mempelajarinya, dan e) pola alih tangan kasus.

Pola manapun yang akan diikuti seorang pelaksana layanan harus memiliki perencanaan/persiapan, sehingga kegiatan tersebut dapat berjalan dengan baik dan dapat disinkronisasikan dengan pelaksanaan pengajaran sehari-hari. Dalam buku Pelayanan Bimbingan dan Konseling berbasis kompetensi Sekolah Dasar, Madrasah Ibtidaiyah sederajat (2002: 17) dinyatakan bahwa guru-guru kelas yang sudah berpengalaman dalam kegiatan bimbingan dan konseling, pada awal tahun ajaran diharapkan menyusun program tahunan bimbingan dan konseling. Program tahunan selanjutnya dirinci menjadi program caturwulanan, dan lebih lanjut lagi dirinci menjadi program bulanan dan satuan kegiatan. Berdasarkan ini dapat dipahami betapa pentingnya sebuah program demi kelancaran sebuah kegiatan.

\section{Peranan Konselor dalam Pengem- bangan Karakter Cerdas}

Istilah karakter bukanlah sesuatu yang baru, karena Ir Sukarno telah mencanangkannya bagi Negara yang baru merdeka dengan ungkapan "notion and character building". Karakter pada dasarnya adalah cara berpikir dan berprilaku individu yang menjadi cirri khasnya dalam bekerjasama dan berinteraksi dengan lingkungan, atau de- 
ngan kata lain karakter adalah jati diri seseorang yang telah terbentuk dalam proses kehidupan oleh sejumlah nilainilai etis yang dimilikinya, berupa polapikir, sikap dan perilakunya (Suparlan: 2). Adapun karakter yang akan dikembangkan adalah karakter cerdas. Menurut Marjohan dalam prosiding seminar Internasional Bimbingan dan Konseling (2012: 185) istilah karakter cerdas pertama kali dimunculkan oleh Prayitno dan B. Manulang. Menurut mereka kehidupan yang dikehendaki untuk setiap manusia adalah kehidupan yang menempuh jalan lurus yang mengikuti kaidah-kaidah nilai dan norma sesuatu dengan fitrah manusia yang berorientasi kebenaran dan keluhuran. Kehidupan dengan jalan lurus itu disebut kehidupan berkarakter. Perilaku berkarakter hendaknya disertai dengan tindakan yang cerdas dan perilaku cerdas dan diisi pula dengan upaya yang cerdas.

Dari pendapat tersebut di atas dapat dipahami bahwa pembentukan karakter cerdas harus diupayakan secara sadar dan terencana. Pembentukan karakter cerdas menjadi tanggung jawab pendidik termasuk konselor/ konselor. Peran dan tanggung jawab konselor dalam pengembangan karakter cerdas terkait dengan UU No. 20 Tahun 2003 tentang Sistem Pendidikan Nasional pasal 3 tentang fungsi dan tujuan. Dari penjelasan fungsi dan tujuan tersebut dapat dipahami bahwa pendidikan tidak hanya sebagai media pengembangan kognitif saja melainkan juga untuk membentuk watak (karakter) dan peradaban bangsa. Dalam kaitan ini, Ahmad Sudrajat (2012, mengutip pendapat Sunaryo, 2006) menulis bahwa karena pekerjaan bimbingan dan konseling adalah pekerjaan berbasis nilai, layanan etis normatif, dan bukan layanan bebas nilai, maka seorang konselor perlu memahami betul hakekat manusia dan perkembangannya sebagai makhluk sadar nilai dan perkembangannya ke arah normatif-etis. Seorang konselor harus memahami perkembangan nilai, namun seorang konselor tidak boleh memaksakan nilai yang dianutnya kepada konseli (peserta didik yang dilayani), dan tidak boleh meneladankan diri untuk ditiru konselinya, melainkan memfasilitasi konseli untuk menemukan makna nilai kehidupannya.

Selanjutnya, materi Pendidikan Karakter dalam Layanan Bimbingan menurut Akhmad Sudrajat (2011: 2) antara lain dapat mencakup: (1) Perilaku seksual; (2) Pengetahuan tentang karakter; (3) Pemahaman tentang moral sosial; (4) Keterampilan pemecahan masalah; (5) Kompetensi emosional; (6) Hubungan dengan orang lain; (7) Perasaan keterikatan dengan sekolah; (8) Prestasi akademis; (9) Kompetensi berkomunikasi; dan (10) Sikap kepada guru. Materimateri sebagaimana disebutkan diharapkan dapat direalisasikan oleh konselor melalui penerapan berbagi jenis layanan konseling. Konselor dapat merealisasikan materi-materi pendidikan karakter tersebut melalui penyelenggaraan tugas pokoknya.

\section{Strategi Pelayanan Pendidikan Karakter melalui Bimbingan dan Konseling}

Strategi pelayanan pendidikan karakter melalui bimbingan dan konseling menurut Akhmad Sudrajat (2011: 2) dapat dilakukan melalui: (1) Layanan Dasar; (2) Layanan Responsif; (3) Bimbingan Individual; dan (4) Dukungan Sistem. Layanan dasar adalah bimbingan yang bertujuan untuk membantu seluruh siswa mengembangkan perilaku efektif dan keterampilan-keterampilan hidup yang mengacu pada tugas-tugas perkembangan siswa SD/MI. Layanan responsive adalah layanan bimbingan yang bertujuan untuk membantu memenuhi kebutuhan yang dirasakan sangat 
penting oleh peserta didik saat ini. Isi layanan responsive adalah bidang: a) pendidikan, b) belajar, c) sosial, d) pribadi, e) karir, f) tata tertib SD, g) narkotika dan perjudian, h) perilaku sosial, dan i) kehidupan lainnya.

Layanan perencanaan individual adalah layanan bimbingan yang membantu seluruh peserta didik dan mengimplementasikan rencana-rencana pendidkan, karir, kehidupan sosial dan pribadinya. Tujuan utama dari layanan ini adalah untuk membantu siswa memantau pertumbuhan dan perkembangan sendiri. Terakhir, dukungan system merupakan kegiatan-kegiatan manajemen yang bertujuan memantapkan, memelihara dan meningkatkan program bimbingan secara menyeluruh.

\section{Hasil}

Penelitian tindakan ini dilaksanakan pada Konselor dan personil sekolah lainnya di MIN Sungai Tarab. Penelitian ini bertujuan untuk meningkatkan kompetensi professional Konselor yang meliputi WPKNS, perancangan program, pelaksanaan program serta evaluasi program. Penelitian ini dilaksanakan pada beberapa siklus dan hasilnya akan diuraikan sebagai berikut.

\section{Siklus Pertama}

Siklus Pertama terdiri dari tiga kegiatan. Kegiatan pertama adalah koordinasi dengan kepala madrasah dan identifikasi persoalan-persoalan yang ada di MIN Sungai Tarab berkaitan dengan pelaksanaan bimbingan dan konseling, Dari kegiatan di atas diperoleh gambaran akan kurangnya pemahaman kepala sekolah tentang tugas dan tanggung jawabnya dalam pelaksanaan BK di MIN, dan kurangnya pemahaman, wawasan dan keterampilan guru kelas dalam pelaksanaan BK di MIN. Berdasarkan apa yang disampaikan oleh kepala madrasah, maka peneliti mencoba mendiskusikan tentang bagian penting dari pelaksanaan BK tersebut yang meliputi program layanan, satuan layanan/ kegiatan pendukung serta satuan kegiatan infusi/ ekstra kurikuler.

Kegiatan kedua adalah diskusi antara peneliti dengan konselor sekolah dan satu orang konselor pendamping peneliti sebagai observer. Pada kesempatan ini topik yang didiskusikan berkaitan dengan BK di SD/MI serta peranan konselor dalam pelaksanaan BK di SD/MI. Dalam hal ini konselor mengemukakan kekurang pahamannya dengan apa yang harus dilakukannya dalam pelaksanaan BK di MIN. Hal ini disebabkan karena latar belakang pendidikannya yang bukan sarjana BK. Berdasarkan penyampaian konselor di atas peneliti mencoba mendiskusikan tentang apa dan bagaimana BK di SD/MI.

Kegiatan ketiga adalah diskusi dengan kepala madrasah dan guru kelas berkaitan dengan tugas dan tanggung jawab mereka dalam pelaksanaan BK di MIN. Dari kegiatan di atas diperoleh gambaran akan kurangnya pemahaman kepala sekolah tentang tugas dan tanggung jawabnya dalam pelaksanaan BK di MIN, dan kurangnya pemahaman, wawasan dan keterampilan guru kelas dalam pelaksanaan BK di MIN. Berdasarkan pelaksanaan tindakan ketiga pada siklus pertama dan hasil pengamatan dari observer maka peneliti berkesimpulan bahwa peningkatan wawasan dan pengetahuan personil madrasah berkaitan dengan pelaksanaan BK di madrasah pada umunya sudah terjadi. Hal ini dibuktikan dengan sudah mampunya personil sekolah tersebut untuk menjelaskan garis besar tugas dan tanggung jawab mereka dalam pelaksanaan BK di madrasah. 


\section{Siklus Kedua}

Kegitan pertama adalah untuk mendampingi konselor dalam pengadministrasian AUM, namun batal dilaksanakan karena konselor madrasah berhalangan hadir dan pengadministrasian AUM dilakukan oleh peneliti sendiri dan didampingi oleh kepala madrasah dan observer.

Kegiatan kedua adalah pengolahan hasil AUM. Pada kesempatan ini peneliti menjelaskan kepada konselor prinsipprinsip pengadministrasian dan pengolahan data individual AUM PTSDL tersebut berkaitan dengan cara mencari skor, menentukan masalah dan mencari porsentase. Dari kegiatan di atas diperoleh gambaran bahwa konselor sudah mengerti cara melakukan pengolahan data individual AUM PTSDL format 4 siswa SD. Hasil dari pengolahan AUM akan diperoleh data tentang permasalahan siswa yang dapat dijadikan dasar dalam penyusunan program berbasis kebutuhan. Program yang disusun nantinya dapat dijadikan dasar dalam pemberian layanan yang sesuai kebutuhan dalam rangka meningkatkan karakter cerdas siswa.

\section{Analisis}

Hasil penelitian menunjukkan adanya peningkatan kompetensi profesional konselor di MIN Sungai Tarab. Peningkatan terjadi pada wawasan dan pengetahuan personil sekolah (kepala madrasah, konselor, guru kelas dan guru mata pelajaran) berkaitan dengan pelaksanaan BK di SD/MI serta keterampilan konselor dalam mengolah data individual AUM PTSDL format 4 murid SD. Personil sekolah merupakan orang yang bertanggung jawab terhadap pelaksanaan BK di sekolah untuk mereka harus paham dengan apa tugas dan tanggung jawab mereka sesuai dengan pendapat Prayitno 2002: 21-22) yaitu keter- libatan masing-masing personil sekolah dalam pelaksanaan BK yaitu: 1) Kepala sekolah adalah penanggung jawab pelaksanaan pendidikan dan sekaligus pelayanan bimbingan dan konseling di sekolah bertugas mengkoordinir kegiatan, menyediakan sarana prasarana dan tenaga, melakukan pengawasan dan pembinaan serta mempertanggungjawabkan pelaksanaan BK di sekolah kepada dinas terkait, 2) Guru kelas adalah guru yang bertugas melaksanakan dan mengelola pendidikan di kelasnya. Guru kelas ini selain mengajar secara penuh juga melaksanakan pelayanan bimbingan dan konseling terhadap siswa-siswa di kelas yang menjadi tanggung jawabnya. Untuk itu seorang guru kelas bertugas merencanakan dan melaksanakan program, mengalihkan siswa-siswa yang memerlukan bantuan lebih lanjut serta mempertanggungjawabkan tugas dan pelaksanaan BK kepada kepala sekolah, 3) Guru agama/ penjaskes adalah guru mata pelajaran yang secara khusus diberi tugas mengajarkan mata pelajaran tersebut di sekolah yang bersangkutan dan membantu guru kelas dalam pelaksanaan pelayanan bimbingan dan konseling, 4) Konselor: konselor yang berasal dari sekolah lain (misalnya SLTP atau SLTA) dapat membantu penyelenggaraan bimbingan dan konseling di SD/MI sederajat. Konselor bersangkutan dapat menyusun program dan menyelenggarakan kegiatan bimbingan dan konseling untuk siswa-siswa di sekolah tersebut sesuai dengan kebutuhan atas dasar permintaan.

Selanjutnya dari penelitian yang dilakukan telah terjadi peningkatan dalam kemampuan konselor mengolah data individual AUM PTSDL seabagai salah satu cara untuk mengidentifikasi masalah dalam rangka penyusunan program. Berkaitan dengan perencanaan program layanan BK di SD Ahmad Juntika dan Akur Sudianto (2005: 29-30) 
menyatakan ada beberapa kegiatan yang perlu dilaksanakan yaitu: a) analisa kebutuhan dan permasalahan siswa, b) penentuan tujuan program layanan yang hendak dicapai, c) analisa situasi dan kondisi di sekolah, d) penentuan jenis kegiatan yang akan dilakukan, e) penetapan metode dan teknik yang akan digunakan dalam kegiatan, f) penetapan personil yang akan melaksanakan, g) persiapan fasilitas dan biaya pelaksanaan, dan $\mathrm{h}$ ) perkiraan tentang hambatan yang akan ditemui.

\section{Kesimpulan}

Penelitian Tindakan layanan yang dilakukan pada konselor dan personil sekolah lainnya di MIN Sungai Tarab ini dilakukan melalui dua siklus dan masing-masingnya ada beberapa kegiatan, yaitu; pada siklus pertama kegiatan pertama dilakukan diskusi dalam rangka peningkatan wawasan kepala madrasah tentang pelaksanaan BK di madrasah. Kegiatan kedua dan ketiga pada siklus pertama ini diskusi dengan konselor dan kegiatan ketiga diskusi dengan guru kelas dan guru mata pelajaran MIN Sungai Tarab. Pada siklus pertama ini sudah terjadi peningkatan wawasan dan pengetahuan personil sekolah tentang pelaksanaan BK di madrasah walaupun guru kelas masih membutuhkan informasi lebih lanjut tentang tugas dan tanggungjawab mereka dalam pelaksanaan BK.

Pada siklus kedua, kegiatan yang sudah terlaksana dua kali. Kegiatan pada siklus kedua ini diarahkan pada peningkatan kompetensi profesional konselor

\section{DAFTAR RUJUKAN}

Ahmad Juntika Nurihsan. 2003. DasarDasar Bimbingan dan Konseling. Bandung: Mutiara

Ahmad Juntika Nurihsan dan Akur dalam penyusunan program yang diawali dengan pengadministrasian dan pengolahan AUM. Setelah pengadministrasian AUM dilaksanakan pengolahan AUM PTSDL format individual. Data yang didapatkan dari pengolahan AUM tersebut dapat dijadikan dasar dalam penyusunan program yang berbasis kebutuhan dalam rangka pengembangan karakter cerdas siswa.

\section{Rekomendasi}

Selanjutnya berdasarkan hasil pelaksanaan penelitian tindakan di atas peneliti merekomendasikan beberapa hal kepada: 1) Kasi Mapenda Kemenag Kabupaten Tanah Datar agar dapat memfasilitasi dan memotivasi konselor di MIN Sungai Tarab untuk menambah wawasan dan keterampilannya mengenai pelaksanaan BK mengingat beliau adalah satu-satunya konselor yang berada di tingkat SD dan diharapkan dapat menjadi contoh bagi SD/MI lainnya. 2) Kepala madrasah untuk tetap mengembangkan BK pada madrasah yang dipimpin dengan cara senantiasa berusaha memfasilitasi personil sekolah untuk memperoleh wawasan, pengetahuan dan keterampilan tentang BK. 3) Konselor diharapkan untuk lebih bersemangat dan meningkatkan motivasi dalam rangka meningkatkan kompetensi profesionalnya. 4) Guru kelas dan guru mata pelajaran diharapkan untuk selalu meningkatkan wawasan dan pengetahuannya tentang BK mengingat pelaksanaan BK di sekolah juga menjadi tanggungjawab mereka.

Sudianto. 2005. Manajemen Bimbingan dan Konseling di Sekolah Dasar: Kurikulum 2004. Jakarta: PT Gramedia Widiasarana Indonesia. 
Ahmad Sudrajat. 2011. Pendidikan Karakter dalam Layanan Bimbingan Dan Konseling. http://akhmadsudrajat.wordpress.c om/2011/10/7

Departemen Agama RI. 1996. Petunjuk Pelaksanaan Administrasi Pendidikan Di Madrasah Ibtidaiyah. Jakarta: Dirjen Pembinaan Kelembagaan Agama Islam Depag RI

Depdiknas, 2002. Pelayanan Bimbingan dan Konseling Berbasis Kompetensi (Sekolah Dasar, Madrasah Ibtidaiyah Dan Sederajat). Jakarta. , 2003. Undang-Undang Republik Indonesia Tentang Sistem Pendidikan Nasional. Jakarta: Citra Umbara

2009. Permen Pendayagunaan Aparatur Negara Nomor 16 Tahun 2009 Tentang Jabatan Funfsional Guru dan Angka kreditnya.

Dewa Ketut Sukardi. 2000. Pengantar Pelaksanaan Program Bimbingan dan Konseling di Sekolah. Jakarta: Rineka Cipta.

, 2008. Pengantar Pelaksanaan Program Bimbingan dan Konseling di Sekolah. Jakarta: Rineka Cipta.

. 2003. Manajemen Bimbingan dan Konseling di Sekolah. Bandung: Alfabeta
Prayitno. (2009). Wawasan Profesional Konseling. Padang: UNP

Prayitno, Mudjiran dan Syahniar (Editor). 2012. Prosiding Seminar Internasional Bimbingan Dan Konseling: Development of Intelligent Character, Agresiveness and Prevention of Drug Abuse through Couseling Application. Padang: Fakultas Ilmu Pendidikan Universitas Negeri Padang.

Sunaryo Kartadinata, dkk, 1998. Bimbingan di Sekolah Dasar. Dirjen Dikti Depdiknas

Suparlan. 2010. Pendidikan Karakter Sedemikian Pentingkah dan Apa Yang Harus Kita Lakukan. http://www.suparlan.com

Yusuf Gunawan. 1992. Pengantar Bimbingan dan Konseling. Jakarta: PT Gramedia Pustaka Utama

Sulipan. Penelitian Tindakan (Action research). Pengembangan Profesi Guru, Kepala Sekolah dan Pengawas. Tersedia dalam http://sekolah.8k.com/rich_text_8. html Diakses tanggal 25 Juni 2010.

Wiriatmadja, Rochiati. (2006). Metode Penelitian Tindakan Kelas untuk meningkatkan kinerja guru dan dosen. Bandung: Remaja Rosda karya. 